\title{
The Relationship of Teenager Reproductive Health Knowledge and Attitudes of Prospective Biology Teacher Student in the Course of Human Anatomy and Physiology in the Biology Department at Universitas Negeri Padang
}

\author{
E Yuniarti ${ }^{1}$, R Darussyamsu ${ }^{2}$, M Fadilah $^{3}$, S R Yanti ${ }^{4}$ \\ ${ }_{1,2,3,4}$ Universitas Negeri Padang, Indonesia \\ elsayuniarti@gmail.com
}

\begin{abstract}
There are many cases of teenager reproductive health caused by low teenager knowledge of reproductive health. This problem must be a concern by various parties, including teachers. Furthermore, some teachers still do not understand how to properly integrate reproductive health material. Therefore, biology teacher candidates are required to have good knowledge and attitudes toward teenager reproductive health. This research is a descriptive study with 40 sample students taking part in the lectures on Human Anatomy and Physiology at Universitas Negeri Padang in 2018. Data were collected using written tests and questionnaires. The result showed that the knowledge is obtained by an average score of 77.71 with good categories, and attitudes with an average score of 86.55 in the excellent category. Based on the results of the study, concluded that the knowledge and attitudes of prospective biology teacher had a very strong correlation.
\end{abstract}

\section{Introduction}

Reproductive health is one of the main problems that occur in the Indonesian teenager. Various reproductive health problems are currently a serious problem, especially for women. Problems surrounding women's reproductive health increase with the presence of cancer that attacks reproductive organs, such as ovarian cancer and cervical cancer. Cancer is also present in men, which is characterized by prostate cancer. In addition, the spread of many sexually transmitted diseases (STDs) is very worrying about reproductive health.

In a teenager, there are significant physical and sexual changes so that sexual attraction to the opposite sex is large enough and sexual drive also develops. According to Erikson $(1950 ; 1963)$, the teenager will adapt to their body changes and learn to accept differences with other individuals, both physical and ideological. Rapid physical changes and hormonal changes are the triggers of serious teenager health problems because of the emergence of sexual motivations that make a teenager vulnerable to reproductive health problems and problems, teenage pregnancies with all the consequences of premarital sex, abortion, sexually transmitted diseases (STDs), HIV-AIDS and narcotics [2]. ${ }^{1,2}$

Copyright (C) 2019, the Authors. Published by Redwhite Press.

Page | 142

This is an open access article under the CC BY-NC license

(http://creativecommons.org/licenses/by-nc/4.0). 
Knowledge can be obtained through education, both formally, informally and informally. School is one of the organizers of formal education which has an important role in providing the right education about reproductive health. Learning about reproductive health has been studied by students from the early semester, namely in the subjects of general biology, animal structure, and animal development. Furthermore, this material will be discussed more fully in human anatomy and physiology. Students will be guided by lecturers who apply courses based on achievement indicators. Biology teacher candidates are also required to have good knowledge and attitudes towards teenager reproductive health material because later biology teacher candidates will come down to the field to teach students in junior high and senior high school.

Considering that most of the teenager time is spent in school, and in school students learn about reproductive system material that is closely related to teenager reproductive health in biology subjects, so there is the role of biology teacher candidates to better understand reproductive system material that is closely related to health teenager reproduction, so that later when the reproductive system material is delivered to students biology prospective student. Students are ready in terms of knowledge and attitudes that should be possessed by a teacher.

However, previous studies showed that teachers have not fully understood how to teach teenager reproductive health oriented to promotive and preventive reproductive health [3]. This is likely to be a factor in students' low knowledge about reproductive health and this continues to the level of students. This has been attempted to be overcome by developing promotive and preventive learning materials for reproductive system materials for teenager reproductive health [4].

Based on the description above, research has been conducted on "the relationship of teenager reproductive health knowledge and attitudes of prospective biology teacher students in the course of Human Anatomy and Physiology in the Biology Department at Universitas Negeri Padang"

\section{Method}

This type of research is descriptive. The study was conducted to determine the relationship of teenager reproductive health knowledge and attitudes of prospective biology teachers in the Department of Biology, Universitas Negeri Padang. This research was conducted at the Biology Department of FMIPA UNP. The time for conducting research is the even semester of the school year 2017/2018. The subjects of this study were students of 2015 biology education at Universitas Negeri Padang. Students number 40 people.

\subsection{Technical analysis of knowledge data}

Sudijono (1996) suggests a formula that can be used to calculate values as follows:

value $=\frac{\Sigma \text { correct answer }}{\Sigma \text { question }} \times 100 \%$

The criteria used for this value are as described by Arikunto (2009) as follows: 5,6

$\begin{array}{ll}\text { Very good } & \text { : if answered correctly } 81-100 \% \\ \text { Good } & : \text { if you answer correctly } 66-80 \% \\ \text { Enough } & : \text { if you answer correctly } 56-65 \% \\ \text { Less } & : \text { if you answer correctly } 41-55 \% \\ \text { Very less } & : \text { if the answer is correct } 0-40 \%\end{array}$

\subsection{Product Moment Correlation}

The formula stated by Arikunto (2009), follows: ${ }^{6}$

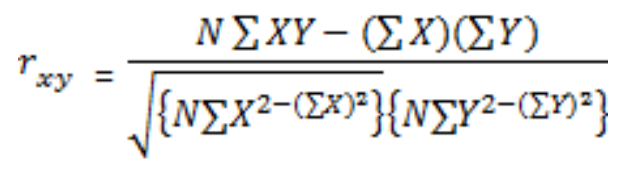




\section{RedWhitepress Global Conferences Series: Sciences and Technology (GCSST), Volume 3, 2020}

Information:

rxy $=$ correlation coefficient between variables $\mathrm{x}$ and $\mathrm{y}$

$\sum x y=$ number of multiplications of $\mathrm{x}$ and $\mathrm{y}$

$\mathrm{x}^{2} \quad=$ square of $\mathrm{x}$

$\mathrm{y}^{2} \quad=$ square of $\mathrm{y}$

\subsection{Technical attitude data analysis}

Sudjana (1991) suggests a formula that can be used to calculate the percentage level of student knowledge as follows:

$$
\mathrm{P}=\frac{f}{N} \times 100 \%
$$

Information:

$$
\begin{array}{ll}
\mathrm{P} & =\text { Percentage } \\
\mathrm{f} & =\text { Frequency of answers } \\
\mathrm{N} & =\text { Number of respondents }
\end{array}
$$

Furthermore, the percentage results are converted to criteria as in Table 1.

Table 1.Student Attitude Criteria

\begin{tabular}{lc}
\hline \multicolumn{1}{c}{ Score } & Criteria \\
\hline $81-100 \%$ & Very good \\
$66-80 \%$ & Good \\
$57-65 \%$ & Enough \\
$41-55 \%$ & Less \\
$0-40 \%$ & Very Less \\
\hline
\end{tabular}

\section{Results and Discussion}

\subsection{Knowledge}

From the data obtained, the results obtained from the knowledge of prospective biology students on teenager reproductive health have an average value of 77.71 in the good category. The level of knowledge of students can be grouped into four groups as can be seen in Figure 1.

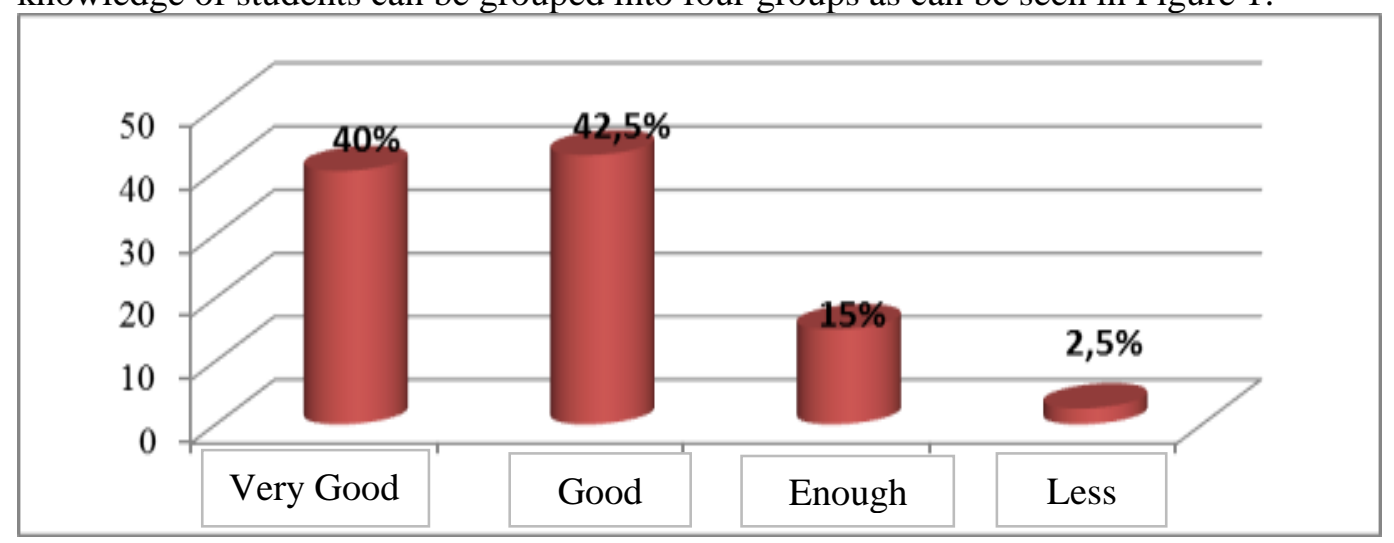

Figure 1. Distribution of Knowledge for Prospective Teachers of Biology Teachers with their Level of Knowledge about Teenager Reproductive Health in the Course of Human Anatomy and Physiology

Based on Figure 1, it is known that these students have varying levels of knowledge. The highest knowledge of prospective biology students regarding teenager reproductive health is in a good 
category, which is as much as $42.5 \%$. This level of student knowledge can be described in accordance with indicators of achievement of competence. This description can be seen in Figure 2.

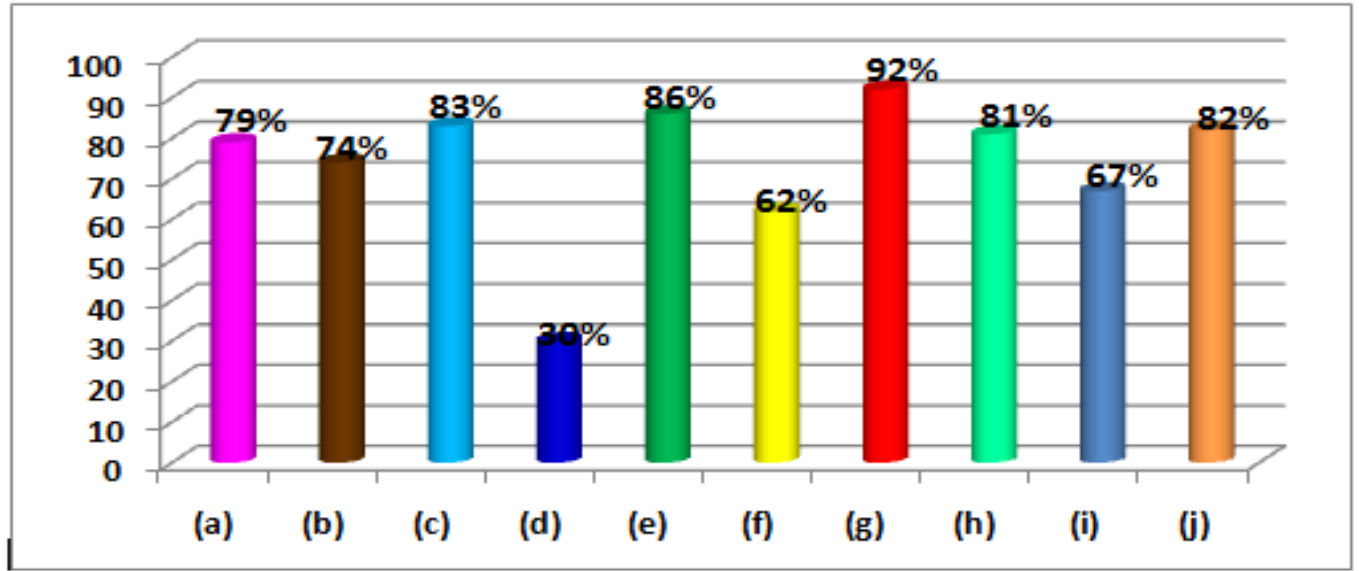

Figure 2. Percentage of Student Knowledge of Biology Teacher Candidates for Each Indicator) Structure, function, and disruption of the organs of the human reproductive system, b) Sex hormones in men and women, c) Stage of the process of forming gametogenesis in men and women, d) Menstrual process in women, e) The process of fertilization and pregnancy, f) Birth and lactation processes, g) Sexually Transmitted Diseases, h) Examples of technology in the reproductive system, i) Relationship to contraceptive methods with population and family planning programs, j) teenager reproductive health.

Based on Figure 2, it can be seen that the attainment of the highest indicator of knowledge is in the indicator $(\mathrm{g})$ of sexually transmitted diseases as much as $92 \%$. While the attainment of the lowest indicator of knowledge is in the indicator (d) the menstrual process in women is $30 \%$.

\subsection{Attitude}

The attitude is divided into three components, namely, the cognitive component includes knowledge of Teenager reproductive health material, the affective component includes positive or negative feelings towards Teenager reproductive health material, and the conative component includes the tendency to act on reproductive health material. This can be seen in Figure 3.

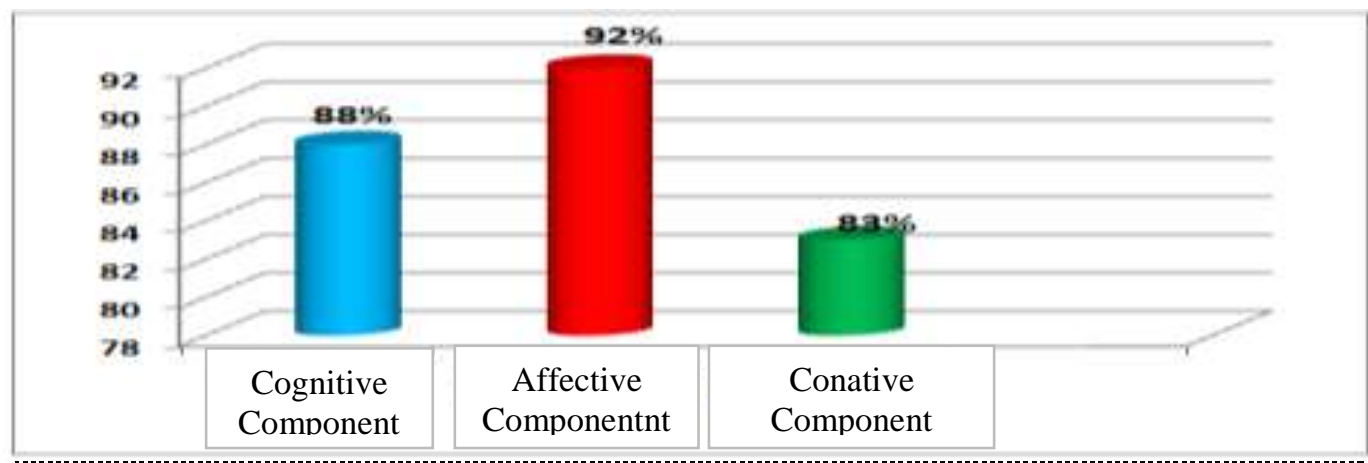

Figure 3. Graph of Levels of Attitude of Prospective Teachers of Biology Students by Components of Cognitive, Affective, and Conative.

Figure 3 shows that prospective biology teacher students show very good attitudes towards teenager reproductive health material. The highest component attitude of prospective biology teacher students is found in the affective component as much as $92 \%$. 


\section{RedWhitepress Global Conferences Series: Sciences and Technology (GCSST), Volume 3, 2020}

\subsection{Attitude}

Attitude is a belief in a person, which signifies his mental readiness for an object, and underlies his actions towards the object. Attitude is divided into three components, namely the cognitive component includes knowledge of teenager reproductive health material, the affective component includes positive or negative feelings towards reproductive health material teenagers, and the conative component includes the tendency to act on reproductive health material.

Based on the results of this study, it is known that the highest level of attitude of prospective biology teacher students is found in the affective component with a percentage of $92 \%$. In the cognitive component, there is a percentage of $88 \%$, and in the conative component, the percentage is $83 \%$. So overall, students have a very good attitude towards teenager reproductive health.

In accordance with what was stated by Notoatmodjo (2010) that good knowledge will lead to a positive attitude towards someone. The attitude that appears in teenagers towards reproductive health tends to be close to a balance between positive attitudes and negative attitudes. ${ }^{8}$

\subsection{Relationship Between Knowledge and Attitude}

The relationship between teenager reproductive health knowledge that is used as a variable (X) and attitudes towards teenager reproductive health is used as a variable (Y). Based on the data analysis that has been done, the correlation results obtained 0.81 with a very strong scale. Using r-value, contribution ( $\mathrm{r} 2$ ) can be determined at valued $65.61 \%$. Further regression analysis informed knowledge variable is predicted to influence the attitude variable as graphically described in Figure 4.

\section{Dependent Variable: $Y$}

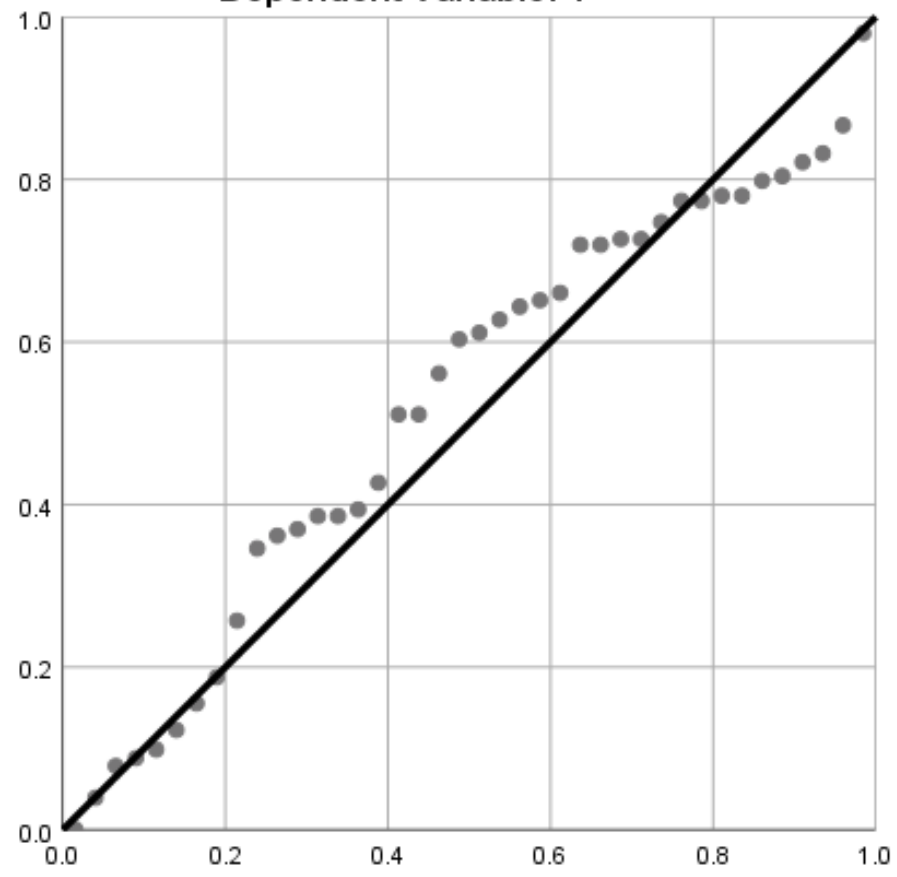

This human anatomy and physiology have a direct connection with teenager reproductive health. This material is one solution to address the problems that occur in teenager reproductive health. In addition, this material is also directly related to the attitude of prospective biology students to teenager reproductive health. Knowledge is the result of knowing, and this happens after people do sensing through the five human senses, namely the senses of sight, hearing, smell, taste, and touch. Most human knowledge is obtained through the eyes and ears [8].

From the results of research conducted on 40 biology education students at the Biology Department, Universitas Negeri Padang, it is known that the knowledge of biology prospective students regarding teenager reproductive health has an average of 77.71 in the good category. Based on the distribution of the level of knowledge on teenager health in grouping categories, the results 
obtained with the highest category are in a good category by $40 \%$. A small level of knowledge on teenager health is in a low category, namely the less category as much as $2.5 \%$.

Based on the data that has been obtained, it is known that prospective biology teacher students at Universitas Negeri Padang have good knowledge of teenager reproductive health. Based on the research of Badriah (2015) states that the level of teenager knowledge about reproductive health in the good category is caused by having obtained information about teenager reproductive health from various sources of information, including print media (magazines, teenage tabloids), electronic media (television), internet media, from friends and health counseling and seminar activities. The results showed that a very good attitude from prospective biology teacher students on teenager reproductive health was followed by very good knowledge of students about the material. This is similar to the opinion of Walgito (2003) stating that a person's attitude towards an object, shows his knowledge of the object.9

Based on the data analysis that has been done, the results of the correlation between the knowledge and attitudes of prospective biology teacher students on reproductive health are 0.81 with a very strong scale. Reproductive health knowledge is important given to teenagers so that teens can use their time to do positive activities. Knowledgeable teenagers are less likely to take various actions that endanger health [10]. Teenagers need to know reproductive health in order to have correct information about the reproductive process and various factors around it. With the right information, it is expected that teens have attitudes and behaviors that are responsible for reproductive health. The contribution of knowledge to attitudes was $65.61 \%$, so knowledge of teenager reproductive health was enough to contribute to the attitude of prospective biology teacher students. Good knowledge will determine a good attitude too, and vice versa if bad knowledge is also a bad attitude. According to Suryani (2006), knowledge is also the strongest factor in changing attitudes. Knowledge and attitudes are the foundation for the formation of teenager morals so that in an ideal person there is the harmony that occurs between knowledge and attitude, where attitude is formed after there is prior knowledge.

\section{Conclusion}

Based on the results of the research that has been done, it can be concluded that the knowledge and attitudes of prospective biology teachers at Universitas Negeri Padang have a very strong correlation with Teenager reproductive health. In this case, knowledge is predicted to influence attitude toward teenager reproductive health. 


\section{RedWhitepress Global Conferences Series: Sciences and Technology (GCSST), Volume 3, 2020}

\section{Reference}

[1] Erikson, E. 1950. Childhood and society. New York: Norton, dan Erikson. 1963. Youth: Change and challenge. Basicbooks.hps://www.bps.go.id /linkTabelStas/view/id/1525 diunduh pada tanggal 20 Februari 2018.

[2] Margaretha, Nuringtyas. R, Rachim, R. 2013. Trauma Kekerasan Masa Kanak Dan Kekerasan Dalam Relasi Intim. Jurnal Makara Seri Sosial Humaniora volume Vol. 17 No (1), 33-42.

[3] Yuniarti, E., Fadilah, M., Darussyamsu, R., \& Nurhayati 2018. Health promotion and preventive contents performed during reproduction system learning; observation in senior high school health promotion and preventive contents performed during reproduction system learning. In IOP Conf. Ser.:Mater.Sci.Eng. 335 0121333. https://doi.org/10.1088/1757-899X/335/1/012133

[4] Yuniarti, E, Fadilah, M, Darussyamsu, R., \& Azmi. 2017. Analysis of adolescent reproductive health effort in reproduction material on junior high school science book. Bioeducation Journal Vol. 1 No 2, 18-27.

[5] Arikunto, S. 2009. Dasar-dasar Evaluasi Pendidikan. Jakarta: Bumi Aksara.

[6] Sudijono.1996.Pengantar Evaluasi Pendidikan. Jakarta: PT. Raja Grafindo Persada.

[7] Sudjana. 1991. Teori-Teori Belajar Untuk Pengajaran. Jakarta : FEUI.

[8] Notoatmodjo, S. 2007. PromosiKesehatandan Ilmu Perilaku. Jakarta: Rineka Cipta.

[9] Walgito, B. 2003.Psikologi Sosial (Suatu Pengantar). Yogyakarta: Andi.

[10] BKKBN Guyton, A dan John, E., Hall. 1996. Buku Ajar Fisiologi Kedokteran. Terjemahan Irawati Setiawan. LMA Ken Ariata Tengadi, dan Alex Santoso. 1997. Jakarta: EGC. 2006. Informasi Dasar Penanggulangan Masalah Kesehatan Reproduksi. Jakarta: BKKBN Pusat.

[11] Suryani E. 2006. Pendidikan Kesehatan Bagian Dari Promosi Kesehatan. F Tranaya : Yogyakarta. 